\title{
Korelasi Positif antara Neutrophil Lymphocyte Count Ratio dan C-Reactive Protein pada Pasien Sepsis Anak
}

\author{
Adri Zamany, Dzulfikar Djalil Lukmanul Hakim, Djatnika Setiabudi \\ Departemen Ilmu Kesehatan Anak Fakultas Kedokteran Universitas Padjadjaran, RSUP Dr. Hasan Sadikin, Bandung
}

Latar belakang. Sepsis merupakan penyebab utama morbiditas dan mortalitas utama pada anak di seluruh dunia. C-reactive protein (CRP) merupakan penanda infeksi yang paling banyak digunakan, tetapi parameter tersebut terkendala tingkat sensitivitas, spesifisitas, ketersediaan alat, dan biaya. Neutrophil-lymphocyte Count Ratio (NLCR) merupakan pemeriksaan yang mudah dan murah, serta banyak digunakan sebagai penanda diagnostik pada berbagai proses inflamasi.

Tujuan. Menganalisis korelasi antara NLCR dan CRP pada pasien sepsis anak.

Metode. Studi analitik observasional menggunakan data sekunder dari register sepsis anak di RSUP Dr. Hasan Sadikin Bandung periode Januari 2019-Desember 2019. Pengambilan data berupa karakteristik pasien, nilai $N L C R$, dan CRP, didapatkan data tidak berdistribusi normal( uji Kolmogorov-Smirnov) maka analisis korelasi dilakukan menggunakan uji Rank Spearman dengan nilai kemaknaan p $<0,05$.

Hasil. Sebanyak 80 subjek memenuhi kriteria inklusi. Median nilai NLCR subjek 2,98 (rentang 0,12-19,38) dan nilai median $C R P$ subjek 2,44 (rentang 0,01-34,04) Nilai NLCR memiliki korelasi bermakna dengan CRP ( $\mathrm{r}=0,310 ; \mathrm{p}=0,005)$.

Kesimpulan. Terdapat korelasi positif yang bermakna antara neutrophil-lymphocyte count ratio dengan CRP pada pasien sepsis anak. Sari Pediatri 2021;23(1):1-5

Kata kunci: anak, neutrophil-lymphocyte count ratio, c reactive protein, sepsis

\section{Positive Correlation between Neutrophil Lymphocyte Count Ratio and C Reactive Protein in Children with Sepsis}

Adri Zamany, Dzulfikar Djalil Lukmanul Hakim, Djatnika Setiabudi

Background. Sepsis is the leading cause of morbidity and mortality in children worldwide. C Reactive Protein (CRP) is the most widely used marker of infection, but these parameters are constrained by sensitivity, specificity, availability of tools, and cost. Neutrophil-lymphocyte Count Ratio (NLCR) is an easy and inexpensive examination, and is widely used as a diagnostic marker of various inflammatory processes. Objective.. Analyzed the correlation between the neutrophil lymphocyte ratio (NLCR) and CRP in children with sepsis.

Method. This observational analytic study used secondary data from the pediatric sepsis register at Dr. Hasan Sadikin Hospital Bandung for the period January 2019-December 2019. Patient characteristics, NLCR values, and CRP were analyzed. Obtained data were not normally distributed (Kolmogorov-Smirnov test), then correlation analysis was performed using the Rank Spearman test with a significance value of $\mathrm{p}<0.05$.

Result. A total of 80 subjects met the inclusion criteria. The subject's median NLCR value was 2.98 (range 0.12-19.38) and the subject's median CRP value was 2.44 (range 0.01-34.04). The NLCR value has a significant correlation with CRP $(\mathrm{r}=0.310 ; \mathrm{p}=0.005)$.

Conclusion. The Neutrophil-Lymphocyte Count Ratio has a significant positive correlation with the CRP value in children with sepsis. Sari Pediatri 2021;23(1):1-5

Keywords: children, neutrophil-lymphocyte count ratio, c reactive protein, sepsis

Alamat korespondensi: Adri Zamany. Departemen Ilmu Kesehatan Anak Fakultas Kedokteran Universitas Padjadjaran Rumah Sakit Dr. Hasan Sadikin, Jalan Pasteur no. 28, Pasteur, Bandung 40161. Email: adrizamanyanwary89@gmail.com 
S epsis merupakan masalah global saat ini karena mempunyai angka kejadian yang tinggi, tatalaksana yang sulit, mortalitas yang tinggi serta memerlukan biaya perawatan yang mahal. ${ }^{1}$ Insidens sepsis pada anak terus meningkat. ${ }^{2}$ Secara global, terdapat sekitar 48,9 juta kasus sepsis pada tahun 2017 dan di negara berkembang memiliki tingkat kematian mencapai 35\%. ${ }^{3,4}$ Sepsis merupakan penyebab utama kematian pada anak di seluruh dunia. ${ }^{3}$ Di unit rawat anak Rumah Sakit Hasan Sadikin, Bandung, yang merupakan Rumah Sakit rujukan Provinsi Jawa Barat, mortalitas pasien sepsis anak yang dirawat mencapai $40 \% .^{5}$ Pemeriksaan penunjang yang mudah, akurat dan cepat diperlukan guna melakukan identifikasi dini pada pasien sepsis anak. Kultur darah merupakan baku emas untuk diagnosis sepsis, tetapi perlu waktu lama dan fasilitas tersebut tidak semua dimiliki rumah sakit sehingga aplikasi di lapangannya sulit. ${ }^{6}$ Pada pasien sepsis, telah diteliti berbagai parameter dan sistem penilaian atau skoring guna menegakkan diagnosis, memperkirakan prognosis, serta menilai/memantau perbaikan dan juga perburukan pasien. ${ }^{6,7,8}$

Neutrophil-lymphocyte count ratio (NLCR) merupakan salah satu parameter yang dapat digunakan sebagai tolak ukur inflamasi sistemik, mudah untuk dihitung, dan tersedia dari panel pemeriksaan darah rutin pasien. ${ }^{?}$ Neutrophil-lymphocyte count ratio didapatkan dari hasil pembagian jumlah neutrofil absolut dengan jumlah limfosit absolut. ${ }^{9,10}$ Pada awal kondisi sepsis terjadi peningkatan jumlah neutrofil diikuti oleh peningkatan jumlah limfosit. Keadaan sepsis yang terus berlangsung akan menyebabkan apoptosis dari limfosit sehingga rasio neutrofil limfosit akan meningkat. ${ }^{11,12}$

Penelitian mengenai NLCR pada setting emergensi menunjukkan bahwa $N L C R$ merupakan prediktor bakteremia yang sama baiknya dengan $C$-reactive protein $(C R P)$ dan hitung leukosit. ${ }^{13}$ Neutrophil-lymphocyte count ratio mudah untuk dihitung dari panel pemeriksaan darah rutin pasien yang dirawat sehingga diharapkan dapat menjadi modalitas baru untuk mendiagnosis sepsis pada anak. Namun, penelitian mengenai korelasi antara NLCR dengan CRP sebagai penanda sepsis pada anak belum ada. Oleh karena itu, penelitian ini dilakukan untuk mengetahui korelasi $N L C R$ dengan CRP di Rumah Sakit Umum Pusat (RSUP) Dr. Hasan Sadikin, Bandung.

\section{Metode}

Penelitian ini merupakan studi analitik observasional dengan menggunakan data sekunder yang berasal dari formulir register sepsis divisi Emergensi dan Rawat Intensif Anak (ERIA) Departemen/KSM Ilmu Kesehatan Anak FK UNPAD/RSUP Dr Hasan Sadikin, periode Januari 2019-Desember 2019. Pencatatan data antara lain usia, jenis kelamin, sumber infeksi, nilai $N L C R$ dan CRP dicatat saat pasien didiagnosis sepsis Data hasil laboratorium diambil sebanyak satu kali pada saat pasien didiagnosis sepsis selama perawatan di RSUP Dr Hasan Sadikin, Bandung.

Kriteria inklusi penelitian adalah anak berusia 1 bulan $-<18$ tahun terdiagnosis sepsis dan tercatat di register sepsis divisi ERIA Departemen/KSM Ilmu Kesehatan Anak FK UNPAD/RSUP Dr Hasan Sadikin dengan hasil pemeriksaan darah rutin, hitung jenis, dan CRP lengkap. Kriteria eksklusi adalah pasien penyakit keganasan di darah dan hati, pasien yang mendapat obat imunosupressan, pasien yang mendapat steroid, dan pasien post trauma atau post operatif.

Dari data yang terkumpul disajikan secara deskriptif dan analitik. Untuk analitik, sebelum dilakukan pengujian statistik terlebih dahulu dilakukan uji normalitas data untuk data numerik yaitu $N L C R$ dan $C R P$ dengan uji Kolmogorov-Smirnov. Analisis korelasi menggunakan rank Spearman karena data tidak berdistribusi normal. Analisis data dilakukan menggunakan program SPSS for versi 20.0 pada derajat kepercayaan 95\% dengan nilai p $<0,05$. Penelitian dilakukan setelah mendapat persetujuan dari Komite Etik Penelitian Kesehatan dan izin penelitian dari direktur utama Rumah Sakit RSUP Dr. Hasan Sadikin Bandung dengan no LB.02.01/X.6.5/243/2020.

\section{Hasil}

Penelitian mengenai korelasi $N L C R$ dengan CRP pada sepsis anak telah dilakukan terhadap 80 subjek yang memenuhi kriteria inklusi. Data karakteristik subjek penelitian tertera pada Tabel 1

Dari tabel karakteristik di atas komposisi berdasarkan jenis kelamin terbanyak laki-laki (56,3\%), rentang usia antara 1 bulan $-<18$ tahun dengan median 18 bulan. Sumber infeksi pasien sepsis anak terbanyak, yaitu infeksi saluran napas $(71,3 \%)$. 
Tabel 1. Karakteristik subjek penelitian $(\mathrm{n}=80)$

\begin{tabular}{lcc}
\hline Karakteristik & Jumlah & $\%$ \\
\hline Jenis kelamin & & \\
$\quad$ Laki-laki & 45 & 56,3 \\
$\quad$ Perempuan & 35 & 43,8 \\
Usia (bulan) & & \\
$\quad 1-23$ & 43 & 53,8 \\
$24-71$ & 22 & 27,5 \\
$72-155$ & 7 & 8,8 \\
$156-216$ & 8 & 10,0 \\
Median: 18 & & \\
Rentang: 1-216 & & \\
Sumber infeksi & & \\
$\quad$ Saluran napas & 57 & 71,3 \\
$\quad$ SSP & 20 & 25,0 \\
$\quad$ Saluran cerna & 3 & 3,8 \\
\hline
\end{tabular}

Tabel 2 Korelasi antara NLCR dan CRP

\begin{tabular}{lcccc}
\hline Variabel & Median & Rentang & $\begin{array}{c}\text { Koefisien } \\
\text { Korelasi (r) }\end{array}$ & Nilai p* \\
\cline { 1 - 3 } NLCR & 2,98 & $0,12-19,38$ & 0,310 & 0,05 \\
\cline { 1 - 3 } CRP & 2,44 & $0,01-34,04$ & & \\
\hline
\end{tabular}

Keterangan : $r=$ Koefisien korelasi Rank Spearman
Hasil pemeriksaan korelasi $N L C R$ dan kadar CRP yang diukur saat pertama kali terdiagnosis sepsis datanya tertera pada Tabel 2 .

Hasil perhitungan korelasi antara nilai $N L C R$ dengan $C R P$ dari 80 subjek penelitian. menunjukkan korelasi antara nilai $N L C R$ dengan kadar $C R P$ diperoleh $\mathrm{r}=0,310(\mathrm{p}=0,005)$ yang bermakna, artinya semakin tinggi kadar CRP nilai NLCR semakin meningkat dengan tingkat korelasi lemah. Untuk lebih jelasnya korelasi antara NLCR dengan kadar CRP tertera pada Gambar 1 berikut.

\section{Pembahasan}

Hasil penelitian menunjukkan bahwa angka kejadian sepsis paling banyak terjadi pada subjek berjenis kelamin laki-laki (56,3\%). Penelitian yang dilakukan pada pasien rawat intensif anak di Belgia dilaporkan bahwa perbedaan insidensi, tingkat keparahan, dan prognosis berbagai kondisi inflamasi akut, seperti sepsis didasari oleh mekanisme yang melibatkan faktor hormonal dan

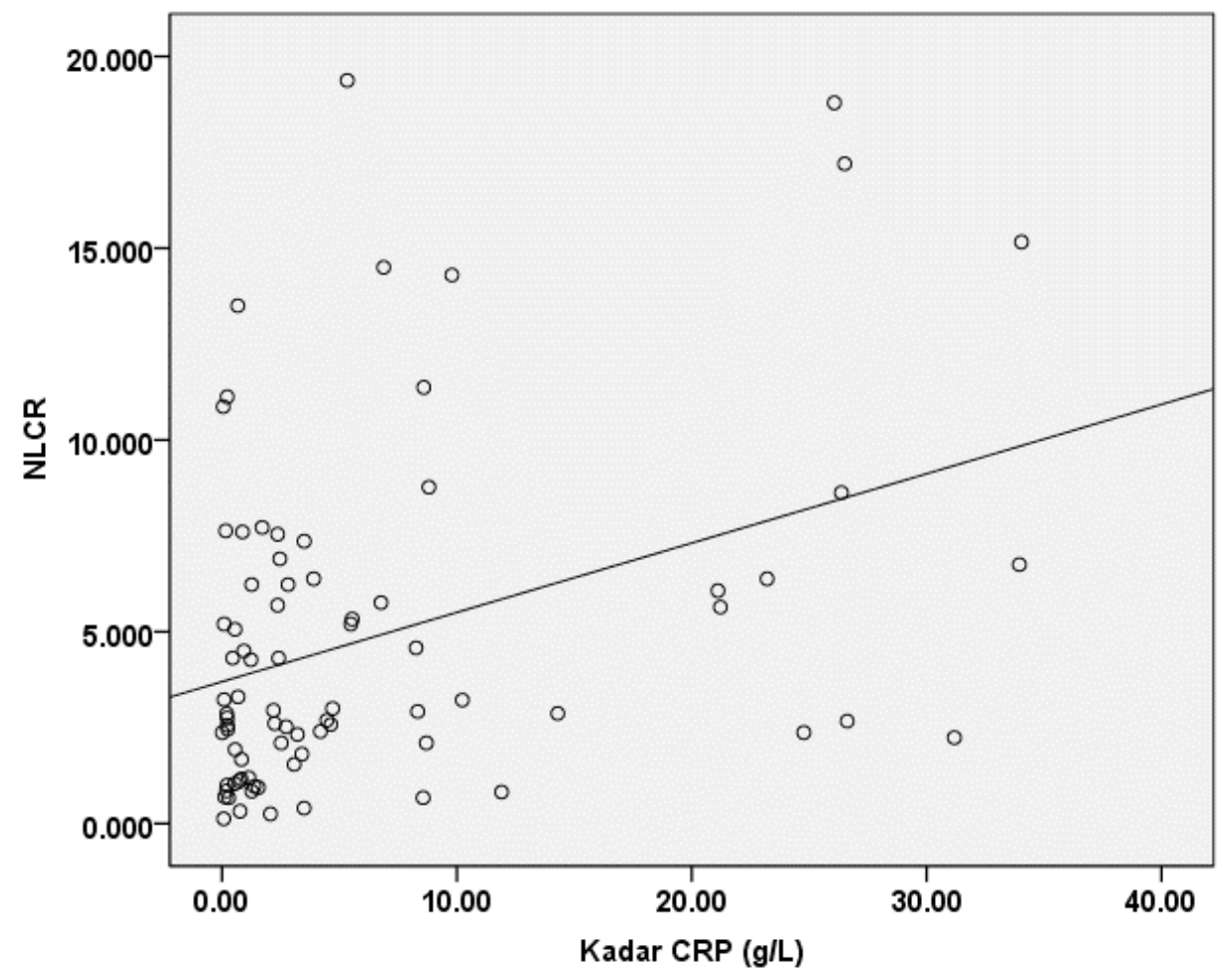

Gambar 1 Korelasi $N L C R$ dengan $C R P$ 
genetik. ${ }^{14}$ Perempuan memiliki respons inflamasi yang lebih kuat dibandingkan dengan laki-laki, khususnya yang melibatkan neutrofil. Hal tersebut dikaitkan dengan respons kortisol terhadap stres fisik yang lebih tinggi pada perempuan. Pada anak perempuan juga dikatakan memiliki lingkungan lebih asam dibanding anak laki-laki yang berkontibusi pada peningkatan perekrutan neutrofil dan sekresi sitokin pro-inflamasi membantu anak perempuan untuk mengeliminasi infeksi lebih baik. ${ }^{14}$

Hasil penelitian menunjukkan bahwa kejadian sepsis paling banyak ditemui pada kelompok usia 1-23 (53,8\%) bulan dengan median 18 bulan diikuti kelompok usia 24-71 $(27,5 \%)$ bulan. Hasil ini serupa dengan yang ditemukan pada penelitian retrospektif yang dilakukan tahun 2018 terhadap 23 penelitian dari tahun 1978 sampai dengan 2016 di 16 negara maju dan 7 negara berkembang. Hasil penelitian tersebut menunjukkan insiden sepsis lebih tinggi pada kelompok anak usia di bawah 5 tahun, terutama kelompok bayi (516 kasus per 100.000 populasi). ${ }^{15}$ Fungsi respons imun bawaan dan adaptif yang berbeda pada anak dan dewasa sangat memengaruhi respons pejamu terhadap infeksi serta respons terapi. Rendahnya produksi IFN- $\gamma$ dan kurangnya respons sel $\mathrm{T}$ sitotoksik pada anak berusia $<2$ tahun mengakibatkan replikasi virus/bakteri menjadi tidak terkontrol sehingga rentan mengalami infeksi berat apabila terinfeksi virus dan bakteri. ${ }^{16}$

Penelitian ini menunjukkan bahwa penyebab sepsis terbanyak adalah infeksi saluran napas $(71,3 \%)$, diikuti dengan infeksi susunan saraf pusat (25\%), dan infeksi saluran cerna $(3,8 \%)$. Studi prevalensi internasional Sepsis Prevalence Outcomes and Therapies (SPROUT) tahun 2015 dari 26 negara, melaporkan rerata usia sepsis adalah 3 tahun, dengan infeksi pada sistem respirasi (40\%) menjadi penyebab yang terbanyak dan 67\% kasus mengalami disfungsi multi organ. ${ }^{17}$

Pada penelitian ini didapatkan nilai median $N L C R$ $2,98(0,12-19,38)$. Hasil NLCR penelitian ini mendekati hasil penelitian terhadap 68 pasien anak dengan sepsis/ bakteremia kelompok usia 1 bulan sampai dengan 5 tahun tahun 2019 di Lithuania yang menunjukkan nilai rata-rata $N L C R 2,69 \pm 2,03$ dan nilai cut-off $N L C R$ 1,58 untuk memprediksi sepsis/bakteremia dengan sensitivitas $73,0 \%$ dan spesifisitas $57,7 \% .{ }^{18}$ Sampai saat ini belum ada kesepakatan mengenai nilai normal NLCR pada anak yang dapat digunakan secara universal, tetapi suatu penelitian di RSUP Sanglah menunjukan nilai cutoff NLCR $\geq 4,67$ merupakan faktor risiko bakteremia pada anak dan dapat digunakan untuk menginisiasi pemberian antibiotik guna mencegah prognosis yang lebih buruk. ${ }^{19}$ Penelitian lain oleh De Jager $\mathrm{dkk}^{9}$ pada pasien dewasa menggunakan cut off point NLCR $>10$ untuk mendiagnosis bakteremia.

Hasil penelitian ini menunjukkan korelasi positif antara nilai $N L C R$ dengan $C R P$ pada pasien sepsis anak. Hal ini menunjukkan bahwa semakin tinggi nilai $N L C R$, semakin meningkat kadar CRP dengan tigkat korelasi rendah. Hasil ini serupa dengan penelitian yang dilakukan oleh di turki pada subjek dewasa dengan sepsis menunjukkan korelasi yang bermakna antara $N L C R$ dan $C R P .{ }^{20}$ Penelitian pada pasien sepsis neonatus di Bandung juga melaporkan adanya korelasi positif antara NLCR dan $C R P .{ }^{21}$ Skor PELOD-2 adalah sistem penilaian yang sering digunakan untuk menggambarkan disfungsi organ multipel. Peningkatan skor PELOD-2 berkaitan dengan efek kumulatif disfungsi organ dan menggambarkan tingkat keparahan sepsis. ${ }^{22}$ Sebuah penelitian pada pasien anak yang dirawat di ruang intensif di India menunjukkan bahwa NLCR dapat memprediksi risiko kematian sama baiknya dengan skor PELOD-2. Penelitian ini menunjukkan peningkatan nilai $N L C R$ dikuti dengan perburukan kondisi klinis dan peningkatan mortalitas pada subjek penelitian. ${ }^{23}$

Pada keadaan sepsis, awalnya didapatkan peningkatan jumlah neutrofil diikuti oleh peningkatan limfosit. Keadaan sepsis yang bertahan akan menyebabkan apoptosis dari limfosit sehingga rasio neutrofil limfosit akan meningkat. Manifestasi neutrofilia dan limfositopenia muncul 4-8 jam setelah paparan infeksi. ${ }^{24}$ Penanda infeksi lainnya, $C R P$, meningkat beberapa kali lipat dalam kondisi infeksi akut. C reactive protein merupakan reaktan fase akut tertentu yang akan meningkat kepekatannya saat terjadi infeksi lokal ataupun sistemik. ${ }^{25}$ Produksi $C R P$ mulai meningkat pada 4-6 jam setelah stimulasi inflamasi dan memuncak pada 48 jam. ${ }^{25}$ Pada penelitian ini didapatkan peningkatan nilai $N L C R$ pada saat pasien terdiagnosis sepsis serta adanya korelasi bermakna antara nilai $N L C R$ dengan $C R P$. Hal tersebut menunjukkan bahwa $N L C R$ dapat digunakan sebagai penanda bakteremia dan sepsis pada setting emergensi dan fasilitas terbatas.

Keterbatasan pada penelitian ini adalah bersifat retrospektif. Penelitian longitudinal diperlukan untuk memantau perubahan nilai $N L C R$ pada pasien sepsis anak serta untuk menentukan nilai cut off $N L C R$ pada pasien sepsis anak. 


\section{Kesimpulan}

Terdapat korelasi positif yang bermakna antara $N L C R$ dengan CRP pada pasien sepsis anak.

\section{Daftar pustaka}

1. Watson RS, Carcillo JA, Linde-zwirble WT, Clermont G, Lidicker J, Angus DC. The epidemiology of severe sepsis in children in the United States. Am J Respir Crit Care Med 2003;167:695-701.

2. Hartman ME, Linde-Zwirble WT, Angus DC, Watson RS. Trends in the epidemiology of pediatric severe sepsis. Pediatr Crit Care Med. 2013;14:686-93.

3. Souza DC De, Machado FR. Epidemiology of Pediatric Septic Shock. J Pediatr Intensive Care 2018;1-8.

4. Rudd KE, Johnson SC, Agesa KM dkk. Global, regional, and national sepsis incidence and mortality, 1990-2017: analysis for the Global Burden of Disease Study. Lancet 2020;395:200-11.

5. Peryoga SU, Hudaya D, Alam A. The Correlation of Arterial Lactate Level and Base Excess with Disease Severity on PELOD-2 Score in Pediatric Sepsis. Pediatr Crit Care Med 2018;19:114.

6. Patel K, McElvania E. Diagnostic challenges and laboratory considerations for pediatric sepsis. J Appl Lab Med 2019;3:587-600.

7. Wulandari A, Martuti S, Kaswadi P. Perkembangan diagnosis sepsis pada anak. Sari Pediatri 2018;19:237-44.

8. Latief A, Chairulfatah A, Alam A, Pudjiadi A, Malisie RF, Hadinegoro SR. Pedoman nasional pelayanan kedokteran Ikatan Dokter Anak Indonesia: diagnosis dan tatalaksana sepsis pada anak. Jakarta: Badan penerbit IDAI; 2016.h.1-47.

9. De Jager CP, van Wijk PT, Mathoera RB, de Jongh-Leuvenink J, van der Poll T, Wever PC. Lymphocytopenia and neutrophillymphocyte count ratio predict bacteremia better than conventional infection markers in an emergency care unit. Crit Care 2010;14:192.

10. Westerdijk K, Simons KS, Zegers M, Wever PC, Pickkers P, de Jager CP. The value of the neutrophil-lymphocyte count ratio in the diagnosis of sepsis in patients admitted to the Intensive Care Unit: A retrospective cohort study. PloS one 2019;14:1-13.

11. Zahorec R. Ratio of neutrophil to lymphocyte counts--rapid and simple parameter of systemic inflammation and stress in critically ill. Bratisl Lek Listy 2001;102:5-14.

12. De Pablo R, Monserrat J, Prieto A, Alvarez-Mon M. Role of circulating lymphocytes in patients with sepsis. Biomed Res
Int 2014;671087:1-12.

13. Mandal RK, Valenzuela PB. Neutrophil-Lymphocyte count ratio on admission as a predictor of Bacteremia and In Hospital Mortality among Sepsis and Septic shock In Patients at Rizal Medical Center. Asian J Med Sci 2018;9:36-40.

14. Lefevre N, Noyon B, Biarent D, Corazza F, Duchateau J, Casimir G. Sex Differences in Inflammatory se and Acid-Base Balance in Prepubertal Children with Severe Sepsis. Shock 2017; $47: 422-8$.

15. Fleischmann-struzek C, Goldfarb DM, Schlattmann P, Schlapbach LJ, Reinhart K, Kissoon N. Review The global burden of paediatric and neonatal sepsis : a systematic review. Lancet Respir.. 2018;6:223-30.

16. Randolph AG, McCulloh RJ. Pediatric sepsis: Important considerations for diagnosing and managing severe infections in infants, children, and adolescents. Virulence 2014;5:172-82.

17. Weiss SL, Fitzgerald JC, Pappachan J, dkk. Global epidemiology of pediatric severe sepsis: the sepsis prevalence, outcomes, and therapies study. Am J Respir Crit Care Med 2015;191:1147-57.

18. Tamelytė E, Vaičekauskienè G, Dagys A, Lapinskas T, Jankauskaitė L. Early blood biomarkers to improve sepsis/ bacteremia diagnostics in pediatric emergency settings. Medicina 2019;55:1-13.

19. Saputra IM, Gustawan W, Utama MD, Arhana BN. Rasio Neutrofil dan Limfosit (NLCR) Sebagai Faktor Risiko Terjadinya Infeksi Bakteri di Ruang Rawat Anak RSUP Sanglah Denpasar. Sari Pediatri 2019;20:354-9.

20. Gozdas H, Gel K, Yasayacak A, Kesgin M, Akdeniz H. The role of hematological parameters in estimating nosocomial sepsis. Electron J Gen Med 2019;16:1-5.

21. Ghrahani R, Yuniati T, Judistiani RT, Setiabudiawan B. Strong Positive Correlation between Neutrophil-to-lymphocyte Ratio and C-reactive Protein in Early Onset Sepsis. Majalah Kedokt Bandung 2019;51:246-52.

22. Leteurtre S, Duhamel A, Salleron J, Grandbastien B, Lacroix J, Leclerc F, Groupe Francophone de Réanimation et d'Urgences Pédiatriques (GFRUP. PELOD-2: an update of the PEdiatric logistic organ dysfunction score. Crit Care Med J 2013;41:1761-73.

23. Schlapbach LJ, Straney L, Bellomo R, MacLaren G, Pilcher D. Prognostic accuracy of age-adapted SOFA, SIRS, PELOD-2, and qSOFA for in-hospital mortality among children with suspected infection admitted to the intensive care unit. Intensive Care Med 2018;44:179-88.

24. Mathews S, Rajan A, Soans ST. Prognostic value of rise in neutrophil to lymphocyte ratio (NLR) and platelet to lymphocyte ratio (PLR) in predicting the mortality in paediatric intensive care. Int J Contemp Pediatr 2019;6:1052.

25. Faix JD. Biomarkers of sepsis. Crit Rev Clin Lab Sci 2013;50:23-36. 